\title{
ANIMALS AS LEGAL BEINGS
}

\section{Contesting Anthropocentric Legal Orders}

In Animals as Legal Beings, Maneesha Deckha critically examines how Canadian law and, by extension, other legal orders around the world, participate in the social construction of the human-animal divide and the abject rendering of animals as property. Through a rigorous but cogent analysis, Deckha calls for replacing the exploitative property classification for animals with a new transformative legal status or subjectivity called "beingness."

In developing a new legal subjectivity for animals, one oriented toward respecting animals for who they are rather than their proximity to idealized versions of humanness, Animals as Legal Beings seeks to bring critical animal theorizations and animal law closer together. Throughout the book, Deckha draws upon the feminist animal care tradition, as well as feminist theories of embodiment and relationality, postcolonial theory, and critical animal studies. Her argument is critical of the liberal legal view of animals and desirous of an animal-friendly cultural shift in the core foundations of anthropocentric legal systems.

Theoretically informed yet accessibly presented, Animals as Legal Beings makes a significant contribution to an array of interdisciplinary debates and is an innovative and astute argument for a meaningful, more-than-human turn in law and policy.

MANEESHA DECKHA is a professor and Lansdowne Chair in Law at the University of Victoria. 


\section{Praise for Animals as Legal Beings}

"Finally! - a comprehensive analysis of animal law that does not rest upon anthropocentric liberal assumptions, but instead advocates for 'beingness' as a new legal subjectivity for animals. A must-read for anyone who cares about more-than-humans."

Irus Braverman, Professor and William J. Magavern Faculty Scholar, The State University of New York at Buffalo

"Animals as property or animals as persons? This dichotomy has consumed scholars debating the legal status of animals. Esteemed feminist and postcolonial scholar Maneesha Deckha breaks through this dichotomy with her argument that animals should occupy the novel legal category of 'beingness.' Her conclusions land in surprising places and must be confronted by anyone seriously concerned with the legal status of animals."

Dale Jamieson, Professor of Environmental Studies and Philosophy and Director of the Center for Environmental and Animal Protection, New York University

"Animals as Legal Beings is an impressive model of research and theoretical literacy. Its breadth is astonishing; Maneesha Deckha is well versed across traditions and theorists. The book's engagement with complex theory is detailed and sensitive to nuance. It is an important contribution to critical thinking about law."

Margot Young, Peter A. Allard School of Law, University of British Columbia

"Well written and highly readable, Animals as Legal Beings is an excellent piece of scholarship. Maneesha Deckha offers a clear theorization of animal legal subjectivity using 'beingness' as her core theoretical value and notes the limitations or unanswered puzzles related to her theorization, as one might expect of such an intellectually humble - in the best sense - scholar."

Anna Grear, School of Law and Politics, Cardiff University

"Maneesha Deckha has emerged as a leading voice in law scholarship which crosses animal studies with feminist and postcolonial theory. This book offers a new contribution to thinking about animals as legal subjects beyond the current impasse between personhood and property. Deckha's innovative approach proposes a new third status - 'beingness' - representing an original attempt to solve a practical dilemma."

Dinesh Wadiwel, School of Social and Political Sciences, The University of Sydney 


\section{Animals as Legal Beings}

Contesting Anthropocentric Legal Orders

MANEESHA DECKHA

UNIVERSITY OF TORONTO PRESS

Toronto Buffalo London 
(C) University of Toronto Press 2021

Toronto Buffalo London

utorontopress.com

Printed in the U.S.A.

ISBN 978-1-4875-0844-9 (cloth) ISBN 978-1-4875-3825-5 (EPUB)

ISBN 978-1-4875-2587-3 (paper) ISBN 978-1-4875-3824-8 (PDF)

\section{Library and Archives Canada Cataloguing in Publication}

Title: Animals as legal beings : contesting anthropocentric legal orders /

Maneesha Deckha.

Names: Deckha, Maneesha, 1972- author.

Description: Includes bibliographical references and index.

Identifiers: Canadiana (print) 20200345443 | Canadiana (ebook)

20200345516 | ISBN 9781487525873 (paper) | ISBN 9781487508449 (cloth) |

ISBN 9781487538255 (EPUB) | ISBN 9781487538248 (PDF)

Subjects: LCSH: Animal welfare - Law and legislation - Canada. |

LCSH: Animals - Law and legislation - Canada. | LCSH: Animal

welfare - Law and legislation. | LCSH: Animals - Law and legislation. |

LCSH: Feminism.

Classification: LCC KE3676.D43 2021 | LCC KF3841.D43 2021 kfmod |

DDC 344.7104/9-dc23

This book has been published with the help of a grant from the Federation for the Humanities and Social Sciences, through the Awards to Scholarly Publications Program, using funds provided by the Social Sciences and Humanities Research Council of Canada.

University of Toronto Press acknowledges the financial assistance to its publishing program of the Canada Council for the Arts and the Ontario Arts Council, an agency of the Government of Ontario.

Canada Council for the Arts
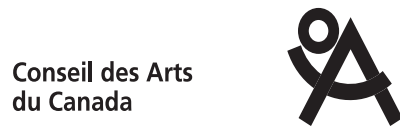

ONTARIO ARTS COUNCIL CONSEIL DES ARTS DE L'ONTARIO

an Ontario government agency un organisme du gouvernement de l'Ontario 
To my dear parents whose love and dedication continue to lift me up And to all animals who never had the chance to bond with their mothers and family like I did and experience the security and beauty in life that follows 
This page intentionally left blank 